\title{
Residents Satisfaction with Training Environment of Saudi Diploma of Family Medicine, Saudi Arabia
}

\author{
Yahia M Al-Khaldi ${ }^{*}$, Kassim M Al-Dawwod ${ }^{2}$, Basima K Al-Khudeer ${ }^{3}$ and Abdullah A Al-Saqqaf ${ }^{4}$ \\ ${ }^{1}$ Joint Program of Family Medicine, Aseer Region, Saudi Arabia \\ ${ }^{2}$ Department of Family \& Community Medicine, Dammam University, Dammam, Saudi Arabia \\ ${ }^{3}$ Postgraduate Center, Ministry Of Health, Riyadh, Saudi Arabia \\ ${ }^{4}$ Joint Program of Family Medicine, Jeddah Region, Saudi Arabia
}

\section{Abstract}

Objective: The objective of this study was to assess the satisfaction of trainees regarding training environment to implement SDFM program in Saudi Arabia.

Methodology: This cross-sectional study was conducted in February 2015 among trainees of Saudi Diploma Family Medicine (SDFM). After the approval of this study by the regional research ethical committee in Aseer region, Saudi Arabia, the questionnaire was distributed to all trainees who attended the final written examination in four examination Centers in Saudi Arabia. The questionnaire consisted of two parts; the first part included personal data of trainees, the second part was about satisfaction with infrastructures (17 items), and administrative aspect of training program (13 items). Satisfaction was assessed using likert scale of five points ( $5=$ very satisfied and $1=$ unsatisfied at all). Data of the questionnaire was managed by SPSS version 15 .

Results: The total participant in this study was 97 trainees, mean age was 34 year, majority were Saudis. Satisfaction was high for many items such adequate and equipped clinics (90-100\%, well equipped laboratory (85\%), medical records (84\%), and clinical guidelines (81\%).Most of aspects scored high points as more than $80 \%$ of participants were satisfied .On other hand, $28 \%$ were unsatisfied about training plan, $23 \%$ were unsatisfied with teamwork, $22 \%$ were unsatisfied with availability of job description for trainees and $21 \%$ were unsatisfied regarding communication with program directors.

Conclusion: SDFM program seems to have a satisfactory educational resources and administrative backgrounds. Certain issues with less satisfaction scores need additional attention especially during reaccreditation process .Future evaluations of the program may wish to address the extent to which the findings of this study influenced the development of the SDFM residency program.

\section{Publication History:}

Received: February 02, 2017

Accepted: May 04, 2017

Published: May 06, 2017

\section{Keywords:}

Saudi Diploma, Family Medicine, Residents, Satisfaction

\section{Introduction}

Residency training programs in Family Medicine (FM) have been in existence in Saudi Arabia for many years [1]. Shortage of qualified family physicians was the main reason behind applying family practice approach in Primary health care centers (PHCCs) in Kingdom of Saudi Arabia (KSA). In addition to 4 years Saudi Board training in Family Medicine (SBFM) that was launched long ago, Saudi Commission for Health Specialty (SCFHS) launched a shorter training program on 2008. Saudi Diploma in Family Medicine (SDFM) is an approved 14 months diploma training program in family medicine.Curriculum of SDFM consisted of theoretical and practical courses and rotations [2]. At present time, there are more than fifty training centers which are accredited by SCFHS. Accreditation of SDFM includes all the following availability of primary care center which fulfill all items in the accreditation documents.

Despite the need to assess this new program, few studies explored the training aspects of both (SBFM) and (SDFM) [3-6]. However, these studies did not explore the satisfaction of residents concerning training environment.

The objective of this study was to assess the satisfaction of trainees regarding training environment required to implement SDFM program in Saudi Arabia.

\section{Materials and Methods}

This cross-sectional study was conducted in February 2015 2015among trainees of Saudi Diploma Family Medicine (SDFM). To
To achieve the objective of this study, the investigators designed a questionnaire based on the Accreditation document of SDFM which was approved by the Central Committee of Accreditation in Saudi commission of Health Specialty [7]. After the approval of this study by the regional research ethical committee in Aseer region, Saudi Arabia , the questionnaire was distributed to all trainees who attended the final written examination in four examination Centers (Riyadh, Jeddah, Abha and Khobar) under the supervision and guidance of four members of the scientific committee of SDFM. The questionnaire consisted of two parts; the first part included personal data of trainees, the second part was about satisfaction with infrastructures (17 items), and administrative aspect of training program (13items).

\section{Methods}

Satisfaction was assessed using likert scale of five points (5 $=$ very satisfied and $1=$ unsatisfied at all). Data of the questionnaire was entered and analyzed by SPSS version 15.Mean, median and standard deviation were calculated for each item indecently and then satisfaction was classified into two main group: "satisfactory" which *Corresponding Author: Yahia M Al-Khaldi, Joint Program of Family Medicine, Aseer Region, Saudi Arabia; E-mail: yahiammh@hotmail.com

Citation: Al-Khaldi YM, Al-Dawwod KM, Al-Khudeer BK, Al-Saqqaf AA (2017) Residents Satisfaction with Training Environment of Saudi Diploma of Family Medicine, Saudi Arabia. Int J Community Fam Med 2: 128. doi: https://doi. org/10.15344/2456-3498/2017/128

Copyright: @ 2017 Al-Khaldi. This is an open-access article distributed under the terms of the Creative Commons Attribution License, which permits unrestricted use, distribution, and reproduction in any medium, provided the original author and source are credited. 
Citation: Al-Khaldi YM, Al-Dawwod KM, Al-Khudeer BK, Al-Saqqaf AA (2017) Residents Satisfaction with Training Environment of Saudi Diploma of Family Medicine, Saudi Arabia. Int J Community Fam Med 2: 128. doi: https://oi.org/10.15344/2456-3498/2017/128

Page 2 of 5

includes the responses of very satisfied, satisfied and satisfied to some degree and "unsatisfactory" which includes unsatisfied and not satisfied at all.

Parts of questionnaire explored the satisfaction of trainees with some aspects of training ( process and outcomes) and discussed earlier elsewhere [4].

\section{Results}

The total participants in this study was 97 trainees, table 1shows their demographic characteristics. Mean age was 34 year, the majority were Saudis, $30 \%$ was from Eastern province centers.

Table 2 shows the degree of satisfaction regarding the availability of infrastructures at training centers. Satisfaction was high for many items such adequate and equipped clinics (90-100\%, well equipped laboratory (85\%), medical records $(84 \%)$, and clinical guidelines $(81 \%)$ . Other items which showed less satisfaction were health information system (56\%), availability of essential drugs (42\%), health education materials (37\%),venue for lectures (36\%),ineffective referral system ( $35 \%)$, unavailability of internet(34\%).

Table 3 depicts the satisfaction of trainees with different aspects of administration in training program. Most of aspects scored high points as more than $80 \%$ of participants were satisfied .On the other hand, $28 \%$ were unsatisfied about training plan, $23 \%$ were unsatisfied with teamwork , 22\% were unsatisfied with availability of job description for trainees and $21 \%$ were unsatisfied regarding communication with program directors.

\begin{tabular}{|l|l|}
\hline $\mathrm{N}$ & 97 \\
\hline Age & $34 \pm 5$ years \\
\hline Sex & \\
\hline Male & $48(49.5)$ \\
\hline Female & $39(40)$ \\
\hline Missing & $10(10 \%)$ \\
\hline Nationality & \\
\hline Saudi & $61(63 \%)$ \\
\hline Non-Saudi & $24(25 \%)$ \\
\hline Missing & $12(12 \%)$ \\
\hline Region & \\
\hline Central & $27(28 \%)$ \\
\hline Eastern & $30(31 \%)$ \\
\hline Western & $25(26 \%)$ \\
\hline Southern & $15(16 \%)$ \\
\hline
\end{tabular}

Table 1 : Demographic characteristics of trainees in SDFM, KSA, 2015.

\section{Discussion}

The mean age of participating residents was higher than the same in other studies from Saudi Arabia [5,6]. This is expected as younger applicants choose to join fellowship compared to diploma training. Earlier studies from Saudi Arabia showed that elder trainees are more likely to have worked in PHC before joining postgraduate programs $[5,6]$. Elder age and previous experience of working in PHC before joining the training program were shown to be associated with a better perception and satisfaction [5,6]. Rate of female trainees is comparable to the rates reported in earlier studies $[5,6]$.

\begin{tabular}{|l|l|l|}
\hline Items & Satisfactory & Unsatisfactory \\
\hline $\begin{array}{l}\text { 1. Adequate number of clinics at } \\
\text { PHCC }\end{array}$ & $100 \%$ & 0 \\
\hline 2. Equipped clinics & $90 \%$ & $10 \%$ \\
\hline 3. Equipped laboratory & $85 \%$ & $15 \%$ \\
\hline 4. Availability of X-rays & $75 \%$ & $25 \%$ \\
\hline $\begin{array}{l}\text { 5. Availability of Health education } \\
\text { materials(booklets, Pamphlets, } \\
\text { posters)/ }\end{array}$ & $63 \%$ & $37 \%$ \\
\hline $\begin{array}{l}\text { 6. Availability of relevant diagnostic } \\
\text { facilities( ECG, PFT) }\end{array}$ & $68 \%$ & $32 \%$ \\
\hline $\begin{array}{l}\text { 7. Availability of essential drugs in } \\
\text { pharmacy }\end{array}$ & $58 \%$ & $42 \%$ \\
\hline 8. Updated medical records & $84 \%$ & $16 \%$ \\
\hline $\begin{array}{l}\text { 9. Availability of clinical guideline } \\
\text { for common health problems }\end{array}$ & $81 \%$ & $19 \%$ \\
\hline $\begin{array}{l}\text { 10. Effective referral system between } \\
\text { PHCC and Hospitals }\end{array}$ & $65 \%$ & $35 \%$ \\
\hline $\begin{array}{l}\text { 11. Availability of health } \\
\text { information system }\end{array}$ & $44 \%$ & $56 \%$ \\
\hline 12. Availability of offices for trainees & $66 \%$ & $34 \%$ \\
\hline $\begin{array}{l}\text { 13. Availability of good venue for } \\
\text { lecturing }\end{array}$ & $64 \%$ & $36 \%$ \\
\hline $\begin{array}{l}\text { 14. Availability of secretary } \\
\text { 15. Availability of up-to-date } \\
\text { textbooks in family medicine }\end{array}$ & $81 \%$ & $19 \%$ \\
\hline $\begin{array}{l}\text { 16. Availability of journals in family } \\
\text { medicine }\end{array}$ & $68 \%$ & $18 \%$ \\
\hline 17. Availability of internet & $66 \%$ & $34 \%$ \\
\hline
\end{tabular}

Table 2: Satisfaction of SDFM trainees with infrastructures facilities at training centers.

\begin{tabular}{|l|l|l|}
\hline Items & Satisfactory & Unsatisfactory \\
\hline 1. Adequate number of trainers & $86 \%$ & $14 \%$ \\
\hline $\begin{array}{l}\text { 2. Varieties of experience among } \\
\text { trainers }\end{array}$ & $84 \%$ & $16 \%$ \\
\hline 3. Availability of organization chart & $85 \%$ & $15 \%$ \\
\hline 4. Availability of training manual & $83 \%$ & $17 \%$ \\
\hline $\begin{array}{l}\text { 5. Availability of policy and } \\
\text { procedures }\end{array}$ & $86 \%$ & $14 \%$ \\
\hline 6. Job description of trainees & $78 \%$ & $22 \%$ \\
\hline 7. Availability of training plan & $72 \%$ & $28 \%$ \\
\hline $\begin{array}{l}\text { 8. Availability of homogenous } \\
\text { teamwork }\end{array}$ & $77 \%$ & $23 \%$ \\
\hline $\begin{array}{l}\text { 9. Availability of the concept of } \\
\text { TQM }\end{array}$ & $80 \%$ & $20 \%$ \\
\hline 10. Availability of CPD & $81 \%$ & $19 \%$ \\
\hline $\begin{array}{l}\text { 11. Availability of training } \\
\text { committee }\end{array}$ & $89 \%$ & $11 \%$ \\
\hline 12. Communication with director & $79 \%$ & $21 \%$ \\
\hline 13. Communication with trainers & $85 \%$ & $15 \%$ \\
\hline
\end{tabular}

Table 3: Satisfaction of SDFM trainees with administrative aspect of training centers. 
Citation: Al-Khaldi YM, Al-Dawwod KM, Al-Khudeer BK, Al-Saqqaf AA (2017) Residents Satisfaction with Training Environment of Saudi Diploma of Family Medicine, Saudi Arabia. Int J Community Fam Med 2: 128. doi: https://oi.org/10.15344/2456-3498/2017/128

Page 3 of 5

Generally, participants expressed high satisfaction with the resources and administrative aspects of SDFM training program. Areas with least satisfaction scores were the availability of essential drugs and patient information system.

The trainees were satisfied about availability and variability of trainers. This is important as shortage of staff was perceived to be a cause of many other unsatisfactory areas of FM training [8]. Participants were satisfied with the exposure to a diversity of patients and diseases at training sites which will enable them to acquire clinical competencies before graduating from SDFM.

Satisfaction with the trainers supervision was adequate in SDFM which could be explained by the acceptable trainers- resident ration which should be kept as (1:2) which comparable to (1:8) elsewhere [8]. Adequate staffing may overcome many weaknesses of poor programs such as inadequate supervision of residents and inadequate staff to facilitate examination preparation [8].The role of adequate supervision in FM residency is vital in learning facilitation as reported in an earlier study in Saudi Arabia [3]. Inadequate supervision has been reported in different settings outside Saudi Arabia $[9,10]$.

The administrative experience of the staff members was another aspect of satisfaction in this study. Poor organization of new FM training programs has been reported elsewhere [9,11,12]. SDFM proved to be a balanced training program. It overcome problems that faced other training programs elsewhere. For example, Turkish trainees were concerned to have more focus on FM-oriented topics that were missed during their hospital rotations [13]. However, Japanese trainees actually felt deprived of adequate clinical teaching during their FM program [12]. This shows the impact of the effort paid on the balanced emphasis in the SDFM curriculum and its execution. This was essential to construct a balance between the clinical procedural skills in general and the FM concepts and special consultation skills that mould a good Family physician.

Generally, this study is representative of all diploma trainees at the time when it was conducted as all trainees were sitting their final examinations. This excluded the nonresponse bias. Being anonymous and self-administered questionnaires made interviewer bias unlikely. This study has overcome such weaknesses in the only one earlier study that evaluated Saudi diploma of family medicine [3] and could be used as baseline for future studies. Limitation of this study included being cross-sectional, and recall bias. Other areas which was not covered in this study and need further studies is satisfaction of residents regarding acquiring of essential core competencies during SDFM training program.

\section{Conclusion and Recommendations}

This study provides an important evaluation of the SDFM residency program from the residents' perspective. The program seems to have a satisfactory educational resources and administrative backgrounds. Certain issues with less satisfaction scores need additional attention especially during reaccreditation process .Future evaluations of the program may wish to address the extent to which the findings of this study influenced the development of the SDFM residency program.

\section{References}

1. Khoja AT (2015) Evaluation of the educational environment of the Saud family medicine residency training program. J Fam Community Med 22 49-56.

2. Saudi Commission For Health Specialties, Saudi Diploma of Family Medicine. Training Manual. 2nd edition.2011; p.15

3. Al-Khathami AD (2012) Evaluation of Saudi Family Medicine training program: The application of CIPP evaluation format. Med Teach 34 S81-S91.

4. Al-Khaldi YM, AIDawood KM, AlKhudeer BK, AISaqqaf AA (2016) Satisfaction of trainees of Saudi Diploma Family Medicine, Saudi Arabia. Educ Prim Care 27: 421-423.

5. Zuhairah A, Al-Dawood KM, Khamis AH (2015) Training in family medicine in Saudi Arabia: Are there any variations among different regions? J Family Community Med 22: 34-38.

6. Zuhairah A, Al-Dawood KM, Khamis AH (2014) Factors affecting family medicine residents perception of achievement of training objectives. Journal of Health Specialties 2: 114-122.

7. Saudi Commission for Health Specialties (2014) Central accreditation Committee. Family Medicine Accreditation and Reaccreditation Form, first version .p.1-8

8. Mbuka DO, Tshitenge S, Setlhare V, Tsima B, Adewale G (2016) New family medicine residency training programme: Residents' perspectives from the University of Botswana. Botswana. Afr J Prm Health Care Fam Med 8: a1098.

9. Wun Y, Lam T, Tsang $L$ (2003) What do family medicine trainees say about their training? Hong Kong Practitioner 5: 59-69.

10. Rourke J, Rourke LL (1995) Rural family medicine training in Canada. Can Fam Physician 41: 993-1000.

11. Murai M, Kitamura K, Fetters MD (2005) Lessons learned in developing family medicine residency training programs in Japan. BMC Med Educ 5: 33-39.

12. Yaman H, Özen $\mathrm{M}$ (2002) Satisfaction with family medicine training in Turkey: Survey of residents. Croat Med J 43: 54-57.

\section{Competing Interests}

The author declares that he has no competing interests. 